\title{
Hubungan Tingkat Pengetahuan dan Sikap dengan Tindakan Pencegahan Osteoporosis pada Wanita Usila di Kelurahan Jati
}

Sri Ganesh Rajaratenam, Rose Dinda Martini, Nur Indrawati Lipoeto

\begin{abstract}
Abstrak
Osteoporosis menjadi masalah kesehatan yang serius di Indonesia dan dunia. Laporan WHO, dianggarkan bahwa setiap 1 dari 3 wanita kecenderungan terkena osteoporosis, pada usia diatas 45 tahun percepatan proses penyakit ini pada wanita meningkat menjadi $80 \%$. Osteoporosis dapat dicegah dari dini, tingkat pengetahuan dan sikap yang dimiliki seseorang mempengaruhi prilakunya.Penelitian ini bertujuan untuk menentukan apakah terdapat hubungan antara tingkat pengetahuan dan sikap dengan tindakan pencegahan osteoporosis. Jenis penelitian ini adalah studi observasional dengan desain cross sectional. Populasi penelitian adalah wanita usila $\geq 60$ tahun yang bertempat tinggal di Kelurahan Jati Kecamatan Padang Timur.Sampel diambil sebanyak 96 orang dengan metode Systemic Random Sampling. Data dikumpulkan dengan kuesioner untuk mengetahui tingkat pengetahuan dan sikap tentang osteoporosis dan tindakan pencegahan yang dilakukan. Data diolah dengan uji statistik chi square menggunakan program SPSS. Hasil analisis univariat diperoleh tingkat pengetahuan osteoporosis wanita usila baik $(87,5 \%)$ tingkat pengetahuan kurang $(12,5 \%)$, sikap tentang osteoporosis baik $(86,5 \%)$ sikap kurang $(13,5 \%)$, tindakan pencegahan baik $(88,5 \%)$ tindakan pencegahan kurang $(11,5 \%)$. Hasil analisis bivariat menunjukkan terdapat hubungan bermakna antara tingkat pengetahuan dengan tindakan pencegahan wanita usila di Kelurahan Jati $(p=0,004)$ dan terdapat hubungan bermakna antara sikap dengan tindakan pencegahan wanita usila di Kelurahan Jati $(p=0,001)$.Penelitian ini memperlihatkan bahwa terdapat hubungan antara tingkat pengetahuan, sikap dengan tindakan pencegahan osteoporosis pada wanita usila di Kelurahan Jati Kecamatan Padang Timur.
\end{abstract}

Kata kunci: tingkat pengetahuan, sikap, tindakan pencegahan, osteoporosis

\begin{abstract}
Osteoporosis is a serious health problem in Indonesia and the world. WHO reports, budgeted that every 1 in 3 women prone to osteoporosis, at the age of over 45 years of accelerating the disease process in women increased to $80 \%$. Osteoporosis can be prevented from early, the level of knowledge and attitude of a person affects his behavior. This study aimed to determine whether there is a relationship between the level of knowledge and attitudes with osteoporosis preventive measures. The study was an observational study with cross-sectional design. The study population was elderly women $\geq 60$ years who reside in the Village of Jati, East Padang district. Samples were taken as many as 96 people with Systemic random sampling method. Data were collected with a questionnaire to determine the level of knowledge and attitudes about osteoporosis and preventive measures undertaken. Data processed by the chi-square statistical tests using SPSS.Results of univariate analysis level of knowledge obtained both elderly osteoporotic women (87.5\%) level of knowledge is less (12.5\%), good attitudes about osteoporosis (86.5\%) less attitude (13.5\%), good preventive measures (88,5\%) less precautions (11.5\%). Results of bivariate analysis showed a significant relationship exists between the level of knowledge of the precautions elderly woman in the village of Jati ( $p$ $=0.004$ ) and there is a significant relationship between the attitude of the precautions elderly woman in the village of Jati $(p=0.001)$. This study shows that there is a relationship between the level of knowledge, attitudes and preventive measures of osteoporosis in elderly women in the village of Jati, East Padang District
\end{abstract}

Keywords:Level of knowledge, behavior, preventive measure, osteoporosis

Affiliasi penulis : Fakultas Kedokteran Universitas Andalas

Korespondensi : Sri Ganesg Rajaratenam, email :

ganeshrajaratenam@gmail.com, Telp: 087895487111

\section{PENDAHULUAN}

Salah satu tolok ukur kemajuan satu bangsa sering kali dilihat dari usia harapan hidup penduduknya. Di Indonesia berkat kemajuan ilmu dan teknologi terutama dibidang kesehatan, meningkatnya mutu dan meluasnya pelayanan dan kesadaran masyarakat akan kesehatan, angka harapan hidup menjadi rata-rata 68.3 pada tahun $2002{ }^{1}$ Penduduk lansia di Indonesia pada tahun 2020 mendatang sudah mencapai angka $11.34 \%$ atau tercatat 28.8 juta orang, balitanya tinggal $6.9 \% .^{2}$ Dari data USA-Bureau of the Census, bahkan Indonesia diperkirakan akan mengalami pertambahan warga lansia terbesar seluruh dunia, antara tahun 1990 - 2025, yaitu sebesar $414 \%{ }^{3}$

Salah satu masalah kesehatan yang perlu mendapatkan perhatian serius pada masa usia lanjut adalah osteoporosis. ${ }^{4}$

Osteoporosis didefinisikan sebagai keadaan dimana Densitas Mineral Tulang (DMT) berada di bawah nilai rujukan. ${ }^{4}$

Penyebab osteoporosis diantaranya, rendahnya hormon estrogen pada wanita, rendahnya aktivitas fisik, kurangnya paparan sinar matahari, kekurangan vitamin $D$, usia lanjut dan rendahnya asupan kalsium. ${ }^{5}$ Hal ini terbukti dengan rendahnya konsumsi rata-rata masyarakat Indonesia yaitu sebesar $254 \mathrm{mg}$ per hari, hanya seperempat dari standar internasional, yaitu 1000-1200 mg per hari untuk orang dewasa. ${ }^{6}$ Osteoporosis dapat dicegah 
sejak dini atau paling sedikit ditunda kejadiannya dengan membudayakan prilaku hidup sehat yang intinya mengkonsumsi makanan dengan gizi seimbang yang memenuhi kebutuhan nutrisi dan kaya kalsium, berolaharga teratur, tidak merokok, dan tidak menkonsumsi alkohol. ${ }^{7}$

Pengetahuan merupakan khasanah kekayaan mental secara langsung atau tidak langsung turut memperkaya kehidupan kita. Setiap pengetahuan mempunyai ciri-ciri yang spesifik mengenai apa (ontologi), bagaimana (epistologi) dan untuk apa (aksiologi). ${ }^{8}$ Pengetahuan yang dimiliki seseorang mempengaruhi prilakunya, semakin baik pengetahuan seseorang maka prilakunya pun semakin baik. ${ }^{9}$

Sikap merupakan reaksi atau respon yang masih tertutup dari seseorang terhadap suatu stimulus atau objek.Manifestasi sikap tidak dapat dilihat langsung tetapi hanya dapat ditafsirkan terlebih dahulu dari perilaku yang tertutup. Sikap secara nyata menunjukkan konotasi adanya kesesuaian reaksi terhadap stimulus tertentu yang dalam kehidupan sehari-hari merupakan reaksi yang bersifat emosional terhadap stimulus sosial. ${ }^{10}$ Sikap juga merupakan evaluasi atau reaksi perasaan mendukung atau memihak (favorable) maupun perasaan tidak memihak (unfavorable) pada objek tertentu. ${ }^{11}$

Dianggarkan bahwa setiap 1 dari 3 wanita memiliki kecenderungan terkena osteoporosis ataupun terdapat kemungkinan sebanyak $67 \%$ untuk golongan wanita mengalaminya. ${ }^{12}$ Osteoporosis hanya dapat dicegah atau ditunda kejadiannya, namun kurangnya pengetahuan masyarakat yang memadai tentang osteoporosis dan pencegahannya sejak dini cenderung meningkatkan kejadian osteoporosis. ${ }^{7}$

Tujuan penelitianini adalah untuk melihat hubungan antara tingkat penetahuan dan sikap dengan tindakan pencegahan osteoporosis di Kelurahan Jati Kecamatan Padang Timur.

\section{METODE}

Jenis penelitian adalah studi observasional dengan desain cross sectional. Populasi penelitian adalah perempuan usia lanjut usia $\geq 60$ tahun di Kelurahan Jati Kecamatan Padang Timur Kota Padang. Sampel berjumlah 96 orang yang diambil berdasarkan metode systematic random sampling pada 9 RW.

Kriteria inklusi sampel adalah perempuan usia lanjut berusia $\geq 60$ tahun, bertempat tinggal di Kelurahan Jati, bersedia ikut dalam penelitian dengan menandatangai informed consent, dan wanita usia lanjut yang mampu berkomunikasi dengan baik.. Kriteria eksklusi antara lain wanita usia lanjut yang pikun, atau sedang mengkonsumsi obat kortikosteroid. Penelitian dilaksanakan dari bulan Mei 2013 sampai Agustus 2013.

Variabel dependen penelitian adalah tindakan pencegahan osteoporosis yang dinyatakan dengan variabel baik atau kurang. Alat yang digunakan adalah keusioner.Hasil ukurnya yaitu (1) Tindakan pencegahan baik skor 22-33 dan tindakan pencegahan kurang skor 11-21.Variabel independen adalah tingkat pengetahuan osteoporosis dan sikap tentang osteoporosis. Data didapatkan melalui wawancara langsung menggunakan kuesioner dengan hasil ukur tingkat pengetahuan baik atau kurang, dan sikap baik atau kurang.

Langkah-langkah pengolahan data yang dilakukan yaitu memeriksa kelengkapan data dari kuesioner, memberikan kode pada setiap data variabel yang telah terkumpul, memasukkan data ke dalam komputer dengan program Microsoft Excell dan Statistical Program for Social Science (SPSS) dan memeriksa kembali data yang telah dimasukkan untuk memastikan bahwa data tersebut telah bersih dari kesalahan. Analisis data terdiri dari analisis univariat dan bivariat. Analisis bivariat digunakan untuk mengetahui hubungan antara dua variabel yaitu diare dengan status gizi menggunakan uji Chi-square dengan derajat kemaknaan $\mathrm{p}<0,05$.

\section{HASIL}

\section{Karakteristik Responden}

Kelompok umur yang mempunyai terbanyak responden adalah umur 65-69 (42,7\%) dengan rerata umur 65,9 (SD $\pm 4,04)$ tahun. Sebagian besar wanita usia lanjut memiliki tingkat pendidikan kurang dengan menyelesaikan pendidikan SD (53,1\%). Sebanyak $63,5 \%$ wanita usila adalah ibu rumah tangga.

\section{Tingkat Pengetahuan wanita usila}

Tabel 1. Distribusi wanita usia lanjut (usila) berdasarkan Tingkat Pengetahuan Osteporasis di Kelurahan Jati

\begin{tabular}{ccc}
\hline $\begin{array}{c}\text { Tingkat } \\
\text { Pengetahuan }\end{array}$ & Frekuensi & $\%$ \\
\hline Baik & 84 & 87,5 \\
Kurang & 12 & 12,5 \\
\hline Jumlah & $\mathbf{9 6}$ & $\mathbf{1 0 0}$ \\
\hline
\end{tabular}

Berdasarkan Tabel 1 dapat dilihat bahwa sebagian besar wanita usila mempunyai tingkat pengetahuan baik.

\section{Sikap wanita usila}

Tabel 2. Distribusi Sikap wanita usila tentang Osteoporosis di Kelurahan Jati.

\begin{tabular}{ccc}
\hline Sikap & Frekuensi & $\%$ \\
\hline Baik & 83 & 86,5 \\
Kurang & 13 & 13,5 \\
\hline Jumlah & 96 & 100 \\
\hline
\end{tabular}

Berdasarkan Tabel 2 dapat dilihat sebagian besar wanita usila mempunyai sikap baik tentang osteoporosis 


\section{Tindakan Pencegahan Osteoporosis}

Tabel 3. Distribusi Tindakan Pencegahan Osteoporosis wanita usila di Kelurahan Jati

\begin{tabular}{ccc}
\hline $\begin{array}{c}\text { Tindakan } \\
\text { Pencegahan }\end{array}$ & Frekuensi & $\%$ \\
\hline Baik & 85 & 88,5 \\
Kurang & 11 & 11,5 \\
\hline Jumlah & 96 & $\mathbf{1 0 0}$ \\
\hline
\end{tabular}

Berdasarkan Tabel 3 dapat dilihat bahwa sebagian besar wanita usila melakukan tindakan pencegahan osteoporosis yang baik.

\section{Analisis Bivariat}

Tabel 4. Hubungan Tingkat Pengetahuan dengan Tindakan Pencegahan Osteoporosis di Kelurahan Jati

\begin{tabular}{cccccccc}
\hline \multirow{2}{*}{$\begin{array}{c}\text { Tingkat } \\
\text { Pengetah } \\
\text { uan }\end{array}$} & \multicolumn{3}{c}{ Tindakan Pencegahan } & Jumlah & $\begin{array}{c}\boldsymbol{p} \\
\text { value }\end{array}$ \\
\cline { 2 - 6 } & $\mathrm{f}$ & $\%$ & $\mathrm{f}$ & $\%$ & $\mathrm{f}$ & $\%$ & \\
\hline Baik & 78 & 92,9 & 6 & 7,1 & 84 & 100 & \\
Kurang & 7 & 58,3 & 5 & 41,7 & 12 & 100 & 0,004 \\
Jumlah & 85 & 100 & $\mathbf{1 1}$ & 100 & $\mathbf{9 6}$ & $\mathbf{1 0 0}$ & \\
\hline $\mathrm{X}^{2}=$ & 12,$336 ; p=0,004$
\end{tabular}

Berdasarkan Tabel 4 dapat dilihat bahwa wanita usila yang melakukan tindakan pencegahan yang baik lebih banyak dari kalangan yang mempunyai tingkat pengetahuan baik. Terdapat hubungan bermakna antara tingkat pengetahuan dengan tindakan pencegahan secara statistik $(p<0,05)$

Tabel 5. Hubungan Sikap dengan Tindakan Pencegahan Osteoporosis di Kelurahan Jati

\begin{tabular}{lccccccc}
\hline \multirow{2}{*}{ Sikap } & \multicolumn{3}{c}{ Tindakan Pencegahan } & Jumlah & $\begin{array}{c}\boldsymbol{p} \\
\text { value }\end{array}$ \\
\cline { 2 - 5 } & \multicolumn{2}{c}{ Baik } & \multicolumn{2}{c}{ Kurang } & & & \\
\cline { 2 - 6 } B & $\%$ & $\mathrm{f}$ & $\%$ & $\mathrm{f}$ & $\%$ & \\
\hline Baik & 78 & 94,0 & 5 & 6,0 & 83 & 100 & \\
Kurang & 7 & 58,3 & 6 & 46,2 & 13 & 100 & 0,001 \\
Jumlah & $\mathbf{8 5}$ & 100 & $\mathbf{1 1}$ & 100 & $\mathbf{9 6}$ & $\mathbf{1 0 0}$ & \\
\hline $\mathrm{x}^{2}=$ & 17,$841 ; p=0,001$ & & & &
\end{tabular}

Berdasarkan table 5 dapat dilihat bahwa wanita usila yang melakukan tindakan pencegahan baik lebih banyak dari wanita usila yang mempunyai sikap baik.

\section{PEMBAHASAN}

\section{Tingkat Pengetahuan}

Sebagian besar wanita usila memiliki tingkat pengethuan osteoporosis yang baik $(87,5 \%)$ dan ditemukan tingkat pengetahuan kurang (12,5\%). Hasil tersebut menunjukkan bahwa persentase wanita usila tingkat pengetahuan baik di Kelurahan Jati sebanding dengan penelitian Geller SE dan Derman R (2001) di Illinois, Amerika Serikat, dimana sebanyak 144 responden $(70 \%)$ mempunyai tingkat pengetahuan yang baik tentang osteoporosis. ${ }^{13} \mathrm{Hal}$ ini mungkin dikarenakan oleh bahan media massa seperti televisi, koran, dan sebagainya banyak memberi pengetahuan, seperti yang disampaikan oleh Wilson TD (2000) bahwa informasi akan memberikan pengaruh pada pengetahuan sesorang, sehingga dalam kaitannya dengan hasil yang didapati. ${ }^{14}$

\section{Sikap}

Didapat bahwa sikap wanita usila tentang osteoporosis berada pada tingkat baik $(86,5 \%)$.. Bila dilihat dari pengetahuan responden yang baik, maka hal ini seperti teori yang dikemukan oleh Notoadmodjo (2003). Menurut Notoadmodjo (2003), pengetahuan yang dipeoleh subjek selanjutnya akan menimbulkan respon batin dalam bentuk sikap terhadap objek yang telah diketahuinya. ${ }^{10}$

\section{Hubungan Tingkat Pengetahuan dengan} Tindakan Pencegahan Osteoporosis

Wanita usila dengan tingkat pengetahuan baik, sebesar $92,9 \%$ melakukan tindakan pencegahan baik dan sebesar $7,1 \%$ melakukan tindakan pencegahan kurang sedangkan, wanita usila yang tingkat pengetahuan kurang diperoleh sebesar $58,3 \%$ dengan tindakan pencegahan baik dan sebesar $41,7 \%$ adalah tindakan pencegahan kurang. Hasil analisis secara statistik menunjukkan bahwa terdapat hubungan yang bermakna antara tingkat pengetahuan osteoporosis dengan tindakan pencegahan osteoporosis yang dilakukan di Kelurahan Jati $(p<0,05)$.

Hasil penelitian ini sebanding dengan penelitian yang dilakukan oleh Maha di Kecamatan Medan Selayang, Medan pada tahun 2009 bahwa terdapat hubungan bermakna antara tingkat pengetahuan dengan tindakan pencegahan osteoporosis dengan nilai $p=0,004(p<0,05){ }^{15}$

\section{Hubungan Sikap dengan Tindakan Pencegahan Osteoporosis}

Berdasarkan hasil penelitian pada wanita usila dengan menggunakan kuesioner, diperoleh wanita usila dengan sikap baik tentang osteoporosis sebanyak $94 \%$ dengan tindakan pencegahan baik, dan $6 \%$ dengan tindakan pencegahan kurang. Sedangkan wanita usila dengan sikap kurang didapatkan $53,8 \%$ dengan tindakan pencegahan yang baik, dan $46,2 \%$ dengan tindakan pencegahan yang kurang.

Hasil analisis menunjukkan terdapatnya hubungan yang bermakna antara sikap dengan tindakan pencegahan osteoporosis dengan nilai $p=0,001(p<0,05)$

Hasil penelitian ini sebanding dengan penelitian yang dilakukan oleh Aditya di Puskesmas Kartasura tahun 2011 bahwa terdapat hubungan yang bermakna antara sikap dengan tindakan pencegahan osteoporosis dengan nilai $p=0,014(p<0,05) .{ }^{16}$

Berdasarkan penelitian ini dapat disimpulkan bahwa tingkat pengetahuan osteoporosis dan sikap tentang osteoporosis di Kelurahan Jati baik dan masih ditemukan wanita usila dengan tingkat pengtahuan dan sikap yang kurang.Tindakan pencegahan yang dilakukan juga masih tinggi dan dari hasil uji statistik terdapat hubungan yang bermakna antara tingkat pengetahuan dan sikap dengan tindakan pencegahan osteoporosis di Kelurahan Jati.

\section{DAFTAR PUSTAKA}

1. Nugroho W. Keperawatan gerontik. Jakarta: ECG; 2000

2. Martono Heru. Pemberdayaan lanjut usia. 2008 (diunduh 20 Mei 2012). Tersedia dari: URL: HYPERLINK 
http://www.gemari.or.id/file/edisi88/gemari8933. pdf

3. Kinsella KG, Taeuber CM. An aging world II, U.S. Dept. of Commerce, Economics and Statistics Administration, Bereau of the Census:Minnesota; 1993.

4. Depkes. Ajak masyarakat lakukan pencegahan osteoporosis. 2002 (diunduh 13 Maret 2012). Tersedia dari: URL: HYPERLINK http://www.depkes.go.id

5. Holick MF. Sunlight and vitamin D for bone health and prevention of autoimmune diseases, cancers, and cardiovascular disease. Am J Clin Nutr December. 2004;(80): 1678S-88S.

6. Depkes. 1 dari 3 wanita dan 1 dari 3 pria memiliki kecenderungan menderita osteoporosis. 2005 (diunduh 13 Maret 2012). Tersedia dari: URL: HYPERLINK http://www.depkes.go.id

7. Depkes. Kecenderungan osteoporosis di Indonesia 6 kali lebih tinggi di banding negeri Belanda. 2005 (diunduh 13 Maret 2012). Tersedia dari: URL: HYPERLINK http://www.depkes.go.id

8. Notoadmodjo S. Promosi kesehatan dan ilmu perilaku. Jakarta: Rineka Cipta; 2007.

9. Notoadmodjo S. Promosi kesehatan, teori dan aplikasi. Jakarta: Rineka Cipta; 2005.

10. Notoadmodjo S. Metodologi penelitian kesehatan. Jakarta: Rineka Cipta; 2002.

11. Azwar S. Sikap manusia, teori dan pengukurannya. Yogyakarta: Pustaka Pelajar; 2003.

12. WHO. BMI classification. 2006 (diunduh 27 April 2013) Tersedia dari: URL: HYPERLINK http://www.who.int/bmi/index.jsp?introPage=intr o 3.html.

13. Geller SE, Derman R. Knowledge, beliefs, and risk factors for osteoporosis among AfricanAmerican and Hispanic women. I Natl Med Assoc. 2001; 93(1): 13-21.

14. Wilson TD, Human Information Behavior. Special Issue on Information Science Research. Sheffield. 2000;3(2).

15. Karolina MS. Hubungan pengetahuan dan pencegahan osteoporosis yang dilakukan lansia di kecamatan Medan Selayang (undergraduate thesis). Medan: Universitas Sumatera Utara; 2009.

16. Pinandita AN. Hubungan antara pengetahuan dengan sikap lansia penderita osteoporosis dalam upaya pencegahan di rumah di puskesmas Kartasura (undergraduate thesis). Surakarta: Universitas Muhammadiyah; 2011. 